\begin{tabular}{l} 
研究助成 \\
成果報告 Hosokawa PowderTechnology Foundation ANNUALREPORT 粉体工学振興財団年報 \\
\hline
\end{tabular}

14108

\title{
細孔径制御型炭素インクによるウェアラブルバイオ電池
}

\section{Fabrication of Wearable Biofuel Cell using Size-controlled Mesoporous Carbon Ink}

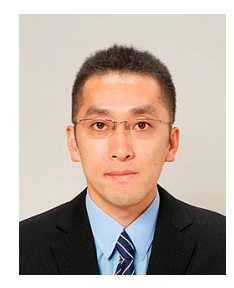

\author{
研究代表者 Research leader：四反田 功 Isao SHITANDA \\ 東京理科大学理工学部工業化学科 講師 \\ Faculty of Science and Technology, Tokyo University of Science, \\ Junior Associate Professor \\ E-mail: shitanda@rs.noda.tus.ac.jp
}

抄録

本研究は, 体液などを燃料とし, ウェアラブル電源として用いることを想定した高出力薄膜型バイ オ燃料電池アレイを開発することを目的とした，出力向上のために，電極構造の検討，基板および 多孔質炭素電極の検討，および燃料供給方法の検討を行った。これらの検討から，紙を基板とした バイオ燃料電池アレイを設計・作製し，電気化学的測定法により評価した. $\mathrm{MgO}$ 鋳型炭素を用い て作製した多孔質炭素電極を適用することで最も大きな電流值を得た，本電極をアノード・カソー ドに用いて, 直列に 4 つ, 並列に 4 つセルを並べたバイオ燃料電池アレイを作製し, 最高出力で約 $1 \mathrm{~mW}$ を得た。

\begin{abstract}
Paper-based biofuel cell have been attracted as a potential application as energy harvesting power sources in Internet of things (IoT) field. In the present study, we newly developed screen-printed paper-based wearable biofuel cell array fabricated by using MgO-templated carbon ink. The paper-based biofuel cell array exhibited a maximum power density of $1 \mathrm{~mW}$. The present flexible paper-based biofuel cell is highly applicable to the development of low cost, flexible, ubiquitous energy devices.
\end{abstract}

\section{研究背景と目的}

バイオ燃料電池とは，酵素を電極触媒に利用 し，糖やアルコールさらには有機物廃液などの バイオマス資源を燃料とし直接発電する発電デ

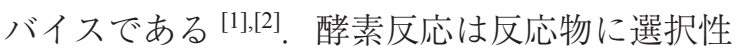
があるため, 他の燃料電池と比較して燃料のク
ロスオーバーといった問題は少ない。また，シ ンプルな構造で, 室温での作動が可能である, 安全性が高いといった利点がある。酵素は工業 的に生産可能であり，資源という観点からも環 境に優しい. 携帯電子機器の電源, 生体内埋め 込み型医療デバイス用電源, ナノスケール機械 のバイオ分子電池といった次世代型電源とし 
て，情報，通信，環境，医療といった分野での 活躍が期待される.

近年, バイオ燃料電池の研究は大きくわけて (i) 高出力化, (ii) 体内埋め込み型デバイス, (iii) 小型かつフレキシブル化の 3 つの分野にわかれ ている.（i）の高出力化については, 酒井らに よって $10 \mathrm{~mW} \mathrm{~cm}^{-2}$ が達成されている ${ }^{[3]}$. (ii) の体内埋め込み型デバイスについては，例えば マウスの生体内に埋め达むタイプなどが報告さ れている ${ }^{[4]}$. (iii) の小型化, フレキシブル化 については, ゲル電解質を用いたフレキシブル バイオ燃料電池基板が報告されている ${ }^{[5]}$.

バイオ燃料電池が次世代型電源として実用化 されるために克服すべき技術的課題として，界 面電子移動速度の向上が挙げられる。申請者ら は，これまでにバイオ燃料電池の界面電子移動 速度や電極構造を電気化学インピーダンス法に よって詳細に解析可能なシステムについて検討 してきた ${ }^{[6]}$. バイオ燃料電池に用いられる酵素 修飾電極の理論モデルを構築し, インピーダン スシミュレーションを行い, 酵素修飾電極を評 価した ${ }^{[7]}$. 上記で得た知見を生かして, 申請者 らは最近多孔質炭素を用いたフレキシブルかつ 高出力な印刷型バイオ燃料電池の開発に成功し た ${ }^{[8]}$. 開発したバイオ燃料電池の構造を図 1 に 示す。

吸水性が高く，印刷性のよい和紙を基板に用 いている。 また，紙を基板としたフレキシブル なバイオセンサの開発にも成功している ${ }^{[9]}$.

紙基板はフレキシブルかつ生体親和性が高い

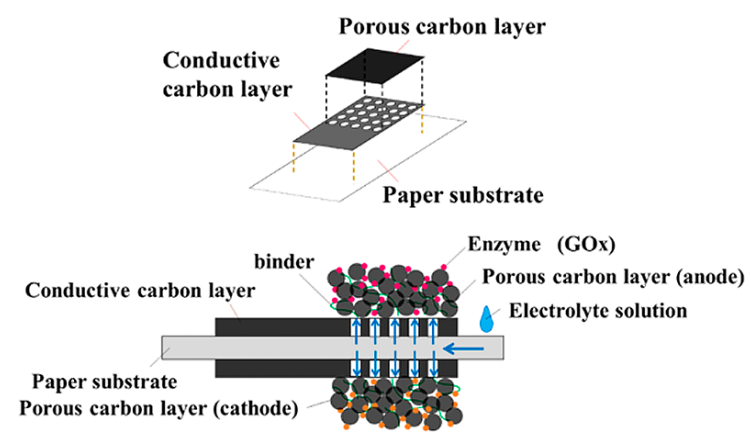

図 1 紙基板に多孔質炭素を印刷したバイオ燃料電 池の模式図.
ため, 肌への着脱も可能であり, 人体から放出 される汗を検出することも可能であるという着 想に至った。 そこで, 本研究では新たに, 紙を 利用した高出力な印刷型ウェアラブルバイオ燃 料電池の開発を行った。

\section{研 究 方 法}

\section{$\mathrm{MgO}$ をテンプレートとした階層構造を有し た多孔質炭素電極の作製}

酵素触媒はソフトで巨大な分子であるので, 酵素を安定に, 高密度で固定化するためには酵 素と同等のサイズのメソ孔が発達した炭素が必 要となる。さらに, 燃料遼供給のためのマクロ 孔が必要である。このため, $\mathrm{MgO}$ 微粒子を用 いた階層構造が制御された多孔質炭素を印刷用 のインクとして調製した. $\mathrm{MgO}$ 鋳型炭素は細 孔径 $38 \mathrm{~nm}$ のものを用いた。

電極評価は電気化学インピーダンス法によっ て行った， $\mathrm{MgO}$ 鋳型炭素㧍よび撥水性の高い ポリテトラフルオロエチレン（PTFE）を用い た多孔質炭素インクをカーボンクロス $(\mathrm{CC})$ に塗布した電極を作製した，本研究では，作製 した電極の特性評価をおこなうため, 電気化学 インピーダンス法による評価に着目した。電解 液の濃度や, 電解液の塩の種類, また酵素の固 定化量などを変化させることで，インピーダン ススペクトルにどのように変化があらわれるの か詳細に検討した。

$\mathrm{MgO}$ 鋳型炭素と, バインダーとして PTFE を1:1の割合で混合し，2-プロパノールを溶 媒として加えた後，超音波分散機によって 10 分間処理することで，多孔質炭素インクを調製 した，電極の基板に CC を用いて, 多孔質イン クをキャストした後に、へラを用いて多孔質炭 素を CC 内に押し込みながら塗布することで, 多孔質炭素電極を作製した，作製した電極にビ リルビンオキシダーゼとメディエーターである ABTS の混合溶液を滴下することで BOD 修飾 電極とした，作製した電極を電気化学インピー ダンス法により評価した。測定条件は, 測定周 


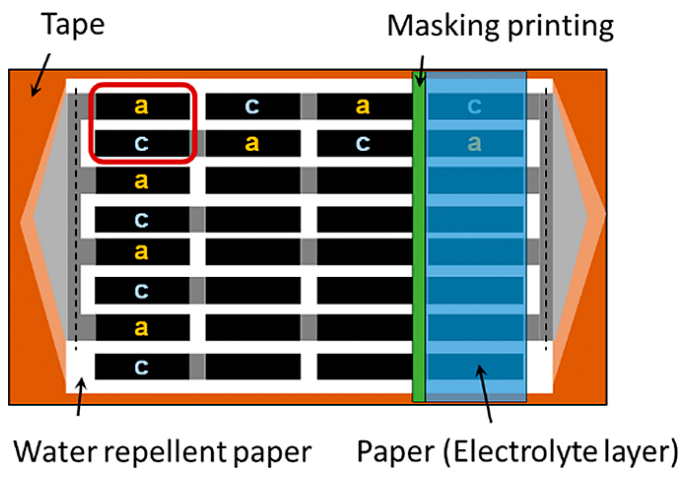

図 2 ウェアラブル化を想定した紙基板バイオ然料 電池アレイの模式図.

波数 $100 \mathrm{kHz} \sim 10 \mathrm{mHz}$ ，対数掃引 5 桁，測定 電位 $0 \mathrm{~V}$ で行なった。

今回作製したバイオ燃料電池アレイ（図 2) は, 画仙紙出雲 (Keynote, Planning) を基板と して用いた. 撥水加工を施した基板に, スクリー ン印刷機（LS-150TV，ニューロング精密工業 社製）を用いてリード部としてカーボンペース 卜 (JELCON CH-10, 十条ケミカル)を印刷した。 その後, 印刷した電極は $120^{\circ} \mathrm{C}$ で 30 分乾燥さ せた. さらにケッチェンブラック，ポリフッ化 ビニリデン（PVdF）を混合し有機溶剤を用い てスラリー化した多孔質炭素インク，もしくは $\mathrm{MgO}$ 鋳型炭素 $(\mathrm{MgOC})$, ポリフッ化ビニリデ ン（PVdF）を有機溶剤と混合しスラリー化し た多孔質炭素インクを電極として 3 層積層印刷 し, $45^{\circ} \mathrm{C}$ で 30 分乾燥させた。

カソードについては, 多孔質炭素電極に UVオゾン処理を 15 分施した. 酸素還元酵素であ るビリルビンオキシダーゼ BOD と界面活性剂 を含む $\mathrm{pH} 7.0$ のリン酸塩緩衝液中に分散させ た酵素溶液（1 unit/uL）を 1 電極あたり $20 \mathrm{uL}$ 滴下した。この電極を $1 \mathrm{~h}$ 減圧乾燥することで カソードとした.

アノードについては, カソード同様に前処理 を施した後，メディエータとしてテトラチアフ ルバレン飽和メタノール溶液を滴下した。そし て,グルコース還元酵素である GOD (和光純薬) を $\mathrm{pH} 7.0$ のリン酸塩緩衝液中に分散させた酵 素溶液（10 unit/uL）を電極あたり $20 \mathrm{uL}$ 滴下
した。この電極を減圧乾燥することでアノード とした。

電解液には $1 \mathrm{M} リ ン$ 酸緩衝液またはグルコー ス $100 \mathrm{mM}$ を含む $1 \mathrm{M}$ リン酸塩緩衝液を用い た. 作製手順を以下に示す.リン酸水素二ナト リウム粉末 (和光純薬) とリン酸二水素ナトリ ウム粉末（和光純薬）を超純水によってそれぞ れ $1 \mathrm{~mol} \mathrm{dm}^{-3}$ の溶液として調整した。調製した リン酸水素二ナトリウム溶液とリン酸二水素ナ トリウム溶液を混合し, pH 7.0 の PBS を調製 した。

バイオカソードとバイオアノードの評価は三 電極法で行った。ポテンシォスタットを用い, 参照極には銀 / 塩化銀飽和 $\mathrm{KCl}$ 電極, 対極には Pt 線を用いた。サイクリックボルタンメトリー は走査速度 $10 \mathrm{mV} / \mathrm{s}$ で行った。測定範囲は, カ ソードについては $-0.3 \sim 0.6 \mathrm{~V}$, アノードにつ いては $-0.3 \sim 0.4 \mathrm{~V}$ とした，電池の評価は測定 は二電極法で行い, 測定範囲は開回路電圧から $0 \mathrm{~V}$ とした，電極上への溶液の供給は, 紙に溶 液を滴下する方法により行った。

\section{研 究 成 果}

図 3 に, 作製した BOD 修飾電極のリン酸塩 緩衝液中におけるサイクリックボルタモグラ ムを図 1 に示す。リン酸塩緩衝液の調製には, ナトリウム塩およびカリウム塩を用いた。カリ ウム塩を用いたサイクリックボルタモグラム

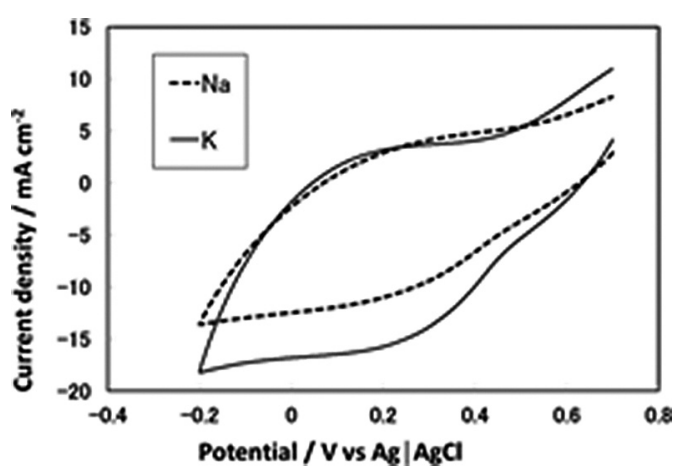

図 3 緩衝液の違いによるバイオカソードの性能 評価. 


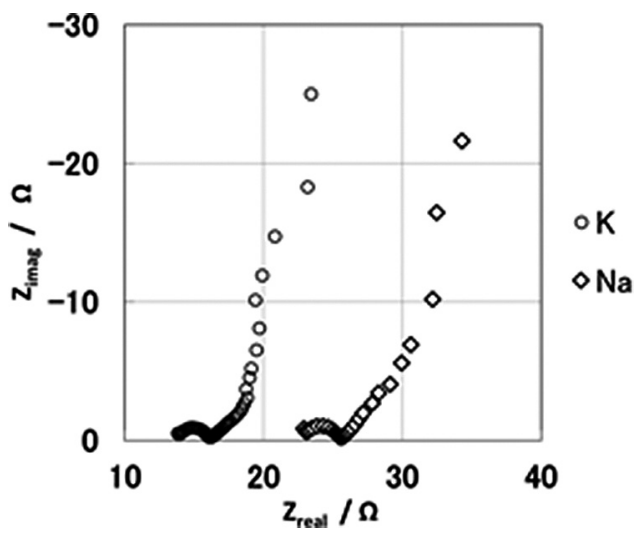

図 4 インピーダンススペクトルによる多孔質炭素 評価.

では最大電流密度が約 $-0.2 \mathrm{~V}$ vs. $\mathrm{Ag} / \mathrm{AgCl}$ で $-18.2 \mathrm{~mA} \mathrm{~cm}^{-2}$ となり, ナトリウム塩を用いた ものと比較して約 1.34 倍大きな值となった。

図 4 にナトリウム塩とカリウム塩を用いた電 極のインピーダンススペクトルを示す。カリウ ム塩を用いて測定した結果はナトリウム塩のも のより，溶液抵抗が約 $9 \Omega$ ほど小さいことがわ かった。またそれぞれのスペクトルには多孔質 に起因する $45^{\circ}$ の立ち上がりが見られた。さら に低周波側でみられる容量性半円は，酵素の酸 素還元反応に起因すると考えられた。このスペ クトルをフィッティングすることで酵素反応お よび電極構造についてのパラメーターを求める ことができた。

次に, ニアスイープボルタンメトリーによ りウェアラブル $\mathrm{BFC}$ アレイの出力評価を行っ た，測定は二電極法で行い，グルコースを溶解 させた電解液を紙に含ませる方法で然料を供給 した。測定条件は, 走査電位開回路電圧〜 $0 \mathrm{~V}$, 走査速度 $1 \mathrm{mV} / \mathrm{s}$, 電解液はグルコース $0.1 \mathrm{~mol} \mathrm{dm}^{-3}$ を含む $1 \mathrm{~mol} \mathrm{dm}^{-3}$ リン酸緩衝液 (pH 7.0) とした。図 5 にウェアラブル $\mathrm{BFC} ア$ レイ $(1 \times 1$ と $4 \times 4)$ の電流一電圧曲線およ び出力曲線を示す。 $1 \times 1$ のセルでは, 開回路 電圧 $0.57 \mathrm{~V}$, 最高出力 $0.064 \mathrm{~mW}$ が得られた。 また, $4 \times 4$ のセルで開回路電圧 $2.21 \mathrm{~V}$, 最高 出力 $0.94 \mathrm{~mW}$ となった. ウェアラブル $\mathrm{BFC} ア$ レイ（4×4）において，オールカーボンでの

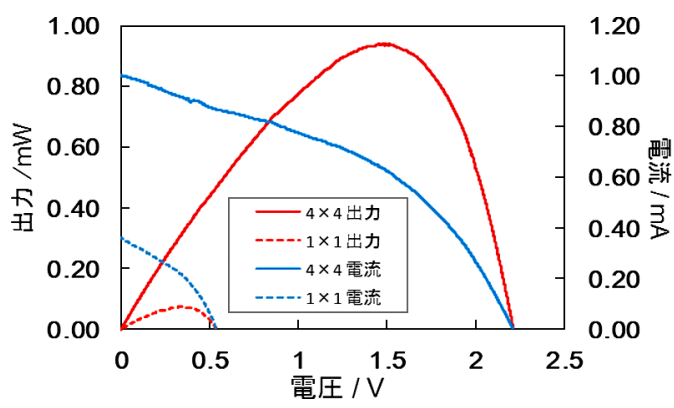

図 5 ウェアラブル BFC アレイの電流 - 電圧曲線と 出力曲線. 赤: $4 \times 4$, 青: $4 \times 1$ カソード : BOD/MgOC 電極, アノード : GOD/TTF/MgOC 電極, 測定溶液：グルコース $0.1 \mathrm{~mol} \mathrm{dm}^{-3}$ 含 むリン酸緩衝液（1 $\left.\mathrm{mol} \mathrm{dm}^{-3}, \mathrm{pH} 7.0\right)$

電池作製で目標としていた約 $1 \mathrm{~mW}$ の出力が得 られた。

\section{参考文献}

[1] Heller, A. Miniature biofuel cells. Physical Chemistry Chemical Physics 2004, 6(2), 209.

[2] Kamitaka, Y.; Tsujimura, S.; Setoyama, N.; Kajino, T.; Kano, K. Fructose/dioxygen biofuel cell based on direct electron transfer-type bioelectrocatalysis. Physical Chemistry Chemical Physics 2007, 9(15), 1793.

[3] Sakai, H.; Nakagawa, T.; Tokita, Y.; Hatazawa, T.; Ikeda, T.; Tsujimura, S.; Kano, K. A high-power glucose/oxygen biofuel cell operating under quiescent conditions. Energy \& Environmental Science 2009, 2(1), 133.

[4] Katz, E.; MacVittie, K. Implanted biofuel cells operating in vivo - methods, applications and perspectivesfeature article. Energy \& Environmental Science 2013, 6(10), 2791.

[5] Miyake, T.; Haneda, K.; Yoshino, S.; Nishizawa, M. Flexible, layered biofuel cells. Biosensors \& Bioelectronics 2013, 40(1), 45.

[6] Shitanda, I.; Tsujimura, S.; Yanai, H.; Hoshi, Y.; Itagaki, M. Electrochemical Impedance Simulation of Branch Structure Porous Carbon Electrode Using Transmission Line Model. Electrochemistry 2015, 83(5), 335.

[7] Shitanda, I.; Ohta, N.; Konya, M.; Hoshino, K.; Nakanishi, J.; Itagaki, M. Faradaic impedance simulation of mediator-type enzyme-functional electrode. Electrochimica Acta 2012, 60, 287.

[8] Shitanda, I.; Kato, S.; Hoshi, Y.; Itagaki, M.; Tsujimura, S. Flexible and high-performance paper-based biofuel cells using printed porous carbon electrodes. Chemical Communications 2013, 49(94), 11110. 
[9] Shitanda, I.; Yamaguchi, T.; Hoshi, Y.; Itagaki, M. Fully Screen-printed Paper-based Electrode Chip for Glucose

\section{外部発表成果}

\section{論文発表}

1. Isao Shitanda, Seiya Kato, Seiya Tsujimura, Yoshinao Hoshi, Masayuki Itagaki, Screenprinted, Paper-based, Array-type, Origami Biofuel Cell, Chemistry Letters, 46 (2017) 726728.

2. Isao Shitanda, Seiya Tsujimura, Misaki Momiyama,Yoshinao Hoshi, Masayuki Itagaki, A Paper-based, mW Power, Biofuel Cell Array using Printable Porous Carbon Electrodes, submitted.

\section{口頭・ポスター発表}

1. Isao Shitanda, "Bio-inspired Electrochemical Devices-Wearable Biofuel Cell and Nanomotor-", Japanese-Chinese Symposium on Photochemistry and Biochemistry National Taiwan University, Taipei, 2015/10/7.

2. Isao Shitanda, "Printable Electrochemistry with Electrochemical impedance analysis and Nanomotor", Mini-workshop on Thunghai University. Tunghai University, Taichun, 2015/10/8.
Detection. Chemistry Letters 2013, 42(11), 1369.

3. 四反田功, “プリンタブルエレクトロケミ ストリーによるウェアラブルバイオ電池”, 電気化学会普及委員会セミナー4（「研究・ 開発のための電気化学測定一次世代エネル ギーデバイス固体界面の解析・評価技術一), 東京理科大学神楽坂キャンパス 1 号館 17 階 記念講堂, 2015 年 11 月 2 日.

4. 四反田功, “ウェアラブルバイオ燃料電池 を搭載した自己駆動型センシングシステ ム”, 化学工学会関東支部第 22 回旬の技術. 見学講演会, イーアスつくば（イーアスホー ル)，2015年 12 月 7 日.

5. 四反田 功, “紙を基板とした印刷型バイオ センサおよびバイオ燃料電池を用いた自己 駆動型センサの開発” 次世代プリンテッド エレクトロニクスコンソーシアム平成 27 年 度第 4 回研究会, 産業技術総合研究所. 臨海副都心センター別館 $11 \mathrm{~F}$ 第 $2 \cdot 3$ 会議室, 平成 28 年 2 月 12 日.

6. 岩下梨沙, 星 芳直, 四反田功, 村田一樹, 辻村清也, 板垣昌幸, カーボンクロスと $\mathrm{MgO}$ 鋳型炭素を用いたバイオカソードの電 気化学インピーダンス測定による特性評価, 2015 年電気化学会秋季大会, 埼玉工大, 平 成 28 年 9 月 11 日。 